Armstrong, D. G., Blaxter, K. L., Graham, N. McC. \& Wainman, F. W. (1959). Anim. Prod. x, I. Blaxter, K. L. (1962). The Energy Metabolism of Ruminants. London: Hutchinson.

Blaxter, K. L. (1964a). Vet. Rec. 76, 1445.

Blaxter, K. L. (1964b). Proc. int. Congr. Nutr. vi Edinburgh, 1963, p. 227. Edinburgh and London: E. and S. Livingstone Ltd.

Brockway, J. M. \& McEwan, E. H. (1969). J. Physiol., Lond., 202, 66r.

Budd, G. M. (1965). F. appl. Physiol. 20, 417.

Davis, T. R. A. (196r). F. appl. Physiol. 16, ror 1.

Davis, T. R. A. (1963). In Temperature, its Measurement and Control in Science and Industry Part III. Biology and Medicine p. 433. [J. D. Hardy, editor]. New York: Reinhold.

Doney, J. M. (1963). F. agric. Sci., Camb. 60, 267.

Doney, J. M. \& Russel, A. J. F. (1968). F. agric. Sci., Camb. 71, 343.

Gelineo, M. S. (1934). Annls Physiol. Phisicochim. biol. 10, 1083.

Glaser, E. M. (1966). The Physiological Basis of Habituation. London: Oxford University Press.

Graham, N. McC. (1960-6r). C.S.I.R.O. Anim. Res. Labs. A. Rep. p. 94.

Halliday, R., Sykes, A. R., Slee, J., Field, A. C. \& Russel, A. J. F. (1969). Anim. Prod. x1, 479.

Hammel, H. T. (1964). In Handbook of Physiology, Sect. 4. Adaptation to the Environment p. 413. [D. B. Dill, editor]. Baltimore: American Physiological Society.

Hart, J. S. (I957). Rev. can. Biol. 16, 133 .

Hensel, H. \& Hildebrandt, G. (1964). In Handbook of Physiology. Sect. 4. Adaptation to the Environment p. 55 [D. B. Dill, editor]. Baltimore: American Physiological Society.

Horvath, S. M., Freedman, A. \& Golden, H. (1947). Am. F. Physiol. r5o, 99.

Hull, D. \& Hardman, M. J. (1970). In Brown Adipose Tissue p. 97 [O. Lindberg, editor]. New York: Elsevier Publishing Co.

Irving, L., Krog, H. \& Monson, M. (1955). Physiol. Zoöl. 28, x73.

Jenkinson, D. M., Noble, R. C. \& Thompson, G. E. (I 968). F. Physiol., Lond. 195, 639.

Joyce, J. P. \& Blaxter, K. L. (1964). Br. F. Nutr. 18, 5.

Mount, L. E. (1968). The Climatic Physiology of the Pig, London: Arnold.

Russel, A. J. F. \& Doney, J. M. (1969). F. agric. Sci., Camb. 72, 59.

Scholander, P. F., Hock, R., Walters, V., Johnson, F. \& Irving, L. (1950). Biol. Bull. 99, 237.

Slee, J. ( ( 966). Anim. Prod. 8, 425.

Slee, J. (1968). Anim. Prod. 10, 265.

Slee, J. (1970). Anim. Prod. 12, 13.

Slee, J. \& Halliday, R. (1968). Anim. Prod. Io, 67 .

Slee, J. \& Sykes, A. R. (1967). Anim. Prod. 9, 333.

Sykes, A. R. \& Slee, J. (I968). Anim. Prod. ro, I7.

Sykes, A. R. \& Slee, J. (1969a). Anim. Prod. 11, 65.

Sykes, A. R. \& Slee, J. (I $969 b)$. Anim. Prod. II, 77.

Wainman, F. W., Blaxter, K. L. \& Pullar, J. D. (1970). F. agric. Sci., Camb. 74, 31 I.

Webster, A. J. F. (1966). Res. vet. Sci. 7, 454.

Webster, A. J. F. (1967). Br. F. Nutr. 2r, 769 .

Webster, A. J. F. \& Blaxter, K. L. (1966). Res. vet. Sci. 7, 466.

Webster, A. J. F., Hicks, A. M. \& Hays, F. L. (1969). Can. F. Physiol. Pharmacol. 47, 553.

Webster, M. E. D. \& Lynch, J. J. (1966). Proc. Aust. Soc. Anim. Prod. 6, 195.

Winfield, C. J., Brown, W., \& Lucas I. A. M. (1968). Anim. Prod. ro, 45 I.

Wodzicka-Tomaszewska, M. (1 g63). N.Z. Yl agric. Res. 6, 440 .

\title{
Minerals in the nutrition of hill cattle and sheep
}

\section{By R. G. Hemingway, Glasgow University Veterinary School, Bearsden, Glasgow}

In systems of animal production which are dependent upon the natural vegetation, as applies with hill cattle and sheep, it is clearly important to establish the pattern of potential mineral intake based on studies of plant composition. Such investigations are subject to major sources of error. Most hill farms are large and cover wide ranges of elevation, drainage and types of soil parent-material. A single farm may embrace 
a variety of types of vegetation and the individual plant components have varying seasonal growth patterns. Superimposed on this botanical variability is the selective grazing behaviour of livestock and the complications of both over-and under-stocking at different times of the year.

Methods for the sampling of hill soils and herbage have been proposed by Calder \& Voss (1957). They concluded that the sampling of soil herbage should be undertaken as two separate operations. To reduce soil contamination, plant material should never be obtained by plucking but by cutting $2 \cdot 5-5 \mathrm{~cm}(\mathrm{I}-2$ in. $)$, according to the habit of growth, above soil level. This undoubtedly reduces the validity of the sample as being representative of more closely grazed material. Nevertheless, some compromise has to be made to exclude soil contamination. Thompson \& Raven (1955) have demonstrated that as little as $2 \%$ soil contamination may completely invalidate the significance attached to herbage mineral concentrations. This is particularly so for cobalt.

The mineral composition of plant material is also related to its stage of maturity. Marston (1934) concluded that the amount of phosphorus in plants was related to their protein content and that both diminished as the plant matured. Thomas \& Trinder (1947) examined the mineral composition of several species of moorland plants (flying bent, deer hair, white bent, stool bent and draw moss) over a single growing season. Notable mean increases were associated with initial growth between late February and early May in respect of $\mathrm{P}(0.14-0.30 \%)$, magnesium (0.10-0.16\%), copper $\left(5 \cdot 3^{-I I} \cdot \mathrm{I} \mathrm{ppm}\right)$ and manganese $(202-355 \mathrm{ppm})$. In each instance the elevated values associated with early growth became progressively reduced with the advance in plant maturity and by late September the concentrations of most minerals in all species were almost as low as for the initial values in February. Calcium and Co concentrations showed little seasonal variation. Thomas, Thompson, Oyenuga \& Armstrong (1952) examined samples of eight grasses, four herbs and four legumes at regular intervals as they approached maturity over a growing season. In the vast majority of instances significant (or almost significant) negative correlations were obtained between mineral composition ( $\mathrm{Ca}, \mathrm{P}, \mathrm{Mg}, \mathrm{Mn}, \mathrm{Cu}$ and $\mathrm{Co}$ ) and advancing age. Thomas, Escritt \& Trinder (1945) recorded that heather contained appreciably more $\mathrm{Ca}, \mathrm{P}, \mathrm{Mg}$ and trace elements than a range of grass species, and that the concentration of all elements diminished during each growing season but not from one year to another. Mitchell (I954) found that remarkably reproducible results for the composition of the trace elements of moorland grazing were obtained when regular samples were obtained from the same area of hill during each of three successive grazing seasons. He concluded that seasonal variations in individual species were largely attributable to maturity effects. Hemingway, MacPherson, Duthie \& Brown (I968) have recorded significant negative correlations between crude protein and the concentrations of $\mathrm{P}$ and $\mathrm{Cu}$ (but not of $\mathrm{Ca}, \mathrm{Mg}$ and $\mathrm{Mn}$ ) in many samples of hays and silages grown in Scotland. It would appear that any attempts to improve systems of grazing management of hill areas which lead to the consumption of younger and less fibrous material will increase the concentration of minerals in the dry matter. 


\section{Mineral composition, herbage digestibility and appetite}

The few studies which have been made concerning the digestibility of plant materials with very low concentrations of minerals have generally been complicated by both the nutritional inadequacy of the materials in other respects and an associated loss of appetite. Kleiber, Goss \& Guilbert ( 1936 ) recorded that growing heifers fed on a diet low in $\mathrm{P}(0.08 \%)$ eventually had only $60 \%$ of the voluntary appetite of those fed a diet adequate in $\mathrm{P}(0.40 \%)$. They were, however, unable to record any changes in the utilization of the digestible encrgy or in the apparent digestibility of the crude protein intake. Hemingway (unpublished) found that increasing the daily $P$ intake from 0.30 to $\mathrm{I} .80 \mathrm{~g} / \mathrm{d}$ did not increase the apparent digestibility of either crude protein or crude fibre by adult sheep maintained on a diet of sugar-beet pulp. Little (1968) recorded that the voluntary intake by sheep of P-deficient lucerne was increased by the addition of supplementary P. Playne (1969) also found that the addition of supplementary $\mathrm{P}$ to lucerne containing only $0.078 \% \mathrm{P}$ caused a slight increase in intake and in the live-weight gain of sheep. This did not occur when the basal diet was spear grass $(0.075 \% \mathrm{P})$ and in neither instance did $\mathrm{P}$ supplementation increase the apparent digestibility of either the total dry matter or the crude protein.

Jones ( 1970 ) increased the Co content of Italian ryegrass from 0.06 to $0.25 \mathrm{ppm}$ and of perennial ryegrass from $0 . I_{1}$ to $0.27 \mathrm{ppm}$ by spraying the herbage with cobalt sulphate in March some 8 weeks before cutting and drying. When fed to sheep, Co supplementation did not increase the dry-matter consumption of either variety. Cobalt did, however, increase the live-weight gain and the digestibility of the organic matter and crude fibre for the perennial ( 0. I I ppm Co) but not for the Italian ryegrass $(0.06 \mathrm{ppm} \mathrm{Co})$. The minimum dietary concentration recommended by the Agricultural Research Council (1965) is $0.10 \mathrm{ppm}$ Co.

\section{Calcium, phosphorus and magnesium}

Hill cows and suckled calves. The minimum recommended intakes of $\mathrm{Ca}, \mathrm{P}$ and $\mathrm{Mg}$ (Agricultural Research Council, r965) for a $450 \mathrm{~kg}$ cow and for a roo kg calf growing at $I .0 \mathrm{~kg} / \mathrm{d}$ are given in Table $\mathrm{I}$. Table $I$ also indicates the concentration of each element required in the dry matter which is presumed to be eaten by the cow (Io $\mathrm{kg} / \mathrm{d})$ and by the calf $(6.751$ milk plus $2 \mathrm{~kg}$ fodder $/ \mathrm{d})$ in order to satisfy the total mineral requirements.

For the hill cow, only the best young herbage is likely to contain more than $0.35 \%$ $\mathrm{P}$. Concentrations in the order of $0.2 \% \mathrm{P}$ are much more likely. Hemingway et al. (I968) have indicated that over $90 \%$ of hays and over $50 \%$ of silages grown in Scotland contain less than $0.25 \% \mathrm{P}$ and that none contained more than $0.35 \% \mathrm{P}$. Accordingly, where there is poor or restricted herbage and supplementation is with hay, silage, straw $(c .0 .15 \% \mathrm{P})$ or sugar-beet pulp $(c .0 .07 \% \mathrm{P})$ there will be an urgent need for $\mathrm{P}$ addition particularly in early lactation. Cereals $(c .0 .3 \% \mathrm{P})$ given in restricted amounts would provide insufficient $\mathrm{P}$ to supplement poor herbage. On the other hand, most hill pastures should contain $0 \cdot 2-0.4 \% \mathrm{Ca}$ and only about $25 \%$ of hays and $5 \%$ of silages were found (Hemingway et al. 1968 ) to contain less than $0.35 \% \mathrm{Ca}$. Calcium 
supplementation of the diet of a hill cow is much less of a general necessity.

Table I. Calcium, phosphorus and magnesium requirements (Agricultural Research Council, 1965) of (a) $450 \mathrm{~kg}$ cow yielding $6.75 \mathrm{l} \mathrm{milk/d} \mathrm{and} \mathrm{(b)} 100 \mathrm{~kg}$ suckled calf growing at $1 \mathrm{~kg} / \mathrm{d}$ and the percentage of each element required in assumed dry-matter (DM) intake to fulfil these requirements

(a) Cow requirements:

Late pregnancy ( $\mathrm{g} / \mathrm{d}$ )

Dietary concentration at $10 \mathrm{~kg} / \mathrm{DM}$ intake/d (\%)

I actation, $6 \cdot 751 / \mathrm{d}(\mathrm{g} / \mathrm{d})$

Dietary concentration at $10 \mathrm{~kg} / \mathrm{DM}$ intake $/ \mathrm{d}(\%)$

$\begin{array}{ccc}\mathrm{Ca} & \mathrm{P} & \mathrm{Mg} \\ & & \\ 16 & 23 & 6.8 \\ 0.16 & 0.23 & 0.07 \\ 34 \cdot 7 & 34 \cdot 6 & 11 \cdot 0 \\ 0.35 & 0.35 & 0 \cdot 1 \mathrm{I}\end{array}$

(b) Suckled calf requirements:

Growth $\mathrm{I} \cdot \mathrm{\circ} \mathrm{kg} / \mathrm{d}(\mathrm{g} / \mathrm{d})$

Supplied in 6.751 milk (g/d)

Dietary concentration at $2 \mathrm{~kg} / \mathrm{DM}$ intake*/d (\%)

$\begin{array}{ccc}27 & 13 & 1.7 \\ 9 & 7 & 0.9 \\ 0.9 & 0.3 & 0.4\end{array}$

*i.e. $2 \mathrm{~kg}$ of herbage or concentrate or both dry matter.

The Agricultural Research Council ( 1965 ) minimum recommended requirement in respect of $\mathrm{Mg}$ implies (Table $\mathrm{x}$ ) for a hill cow that herbage or conserved fodder should contain about $0.07 \%$ for pregnancy or about $0.11 \%$ during lactation. Some $20 \%$ of Scottish hays contain less than $0.075 \% \mathrm{Mg}$ and about $90 \%$ less than $0.125 \%$ $\mathrm{Mg}$ (Hemingway et al. 1968). While the range of the natural $\mathrm{Mg}$ concentration in hill pastures during the winter is not known, it is unlikely to be much greater than $0.10-0.15 \%$ and, in consequence, many hill cows are in all probability receiving a very marginal intake of $\mathrm{Mg}$ especially during lactation.

Many field cases of hypomagnesaemic tetany in hill cows have been associated with a generalized state of continued undernutrition and exposure to adverse climatic conditions. The provision of additional food in the form of hay or more sheltered conditions frequently improves the situation without the need for direct mineral supplementation. (e.g. Inglis, Weipers \& Marr, I954).

It has been stated that $\mathrm{Mg}$ depletion of adult bone does not occur in hypomagnesaemia. Cunningham $\left(\mathrm{I}_{93} 6 a, b\right)$ indicated that the $\mathrm{Mg}$ concentration in bone ash was the same for hypomagnesaemic $(0.42-0.64 \% \mathrm{Mg})$ as for normal $\left(0.45^{-}\right.$ $0.67 \% \mathrm{Mg}$ ) animals. Allcroft (1960) found that the range of $\mathrm{Mg}$ concentrations found in bone ash for four cattle following 4-5 months of hypomagnesaemia was $0.46-0.49 \% \mathrm{Mg}$ compared with a range of from $0.52-0.69 \% \mathrm{Mg}$ where the period of hypomagnesaemia was probably much less. Recently, N. A. Brown \& N. S. Ritchie (unpublished observations) have recorded a mean concentration in the ash of the tail bone of only $0.45 \% \mathrm{Mg}$ for ten adult hill cows which died of suspected hypomagnesaemic tetany. Four of these ten animals had concentrations in the range $0.3 \mathrm{I}-0.38 \% \mathrm{Mg}$. Depletion of bone $\mathrm{Mg}$ following long-term dietary inadequacy is thus a marked possibility.

Brown \& Ritchie (unpublished) have also found a mean concentration of only $0.24 \% \mathrm{Mg}$ (range, $0.09-0.46 \%$ ) in the ash of the tail bone of sixteen suckled calves 
which died of suspected hypomagnesaemic tetany. This is in good agreement with a critical value of below $0.35 \% \mathrm{Mg}$ in the bone ash of dairy calves suggested by Smith (1964).

The long-term supplementation of the diet of hill cows with a suitable mineral mixture (containing $\mathrm{Mg}$ ) given well in advance of the expected time for the development of clinical cases is a sensible measure. Such a mixture could be incorporated into supplementary concentrates. Practical experience in the field would seem to indicate that free-access mineral supplements containing about $25 \%$ calcined magnesite are more popular than those containing about $50 \%$. Hemingway \& Ritchie (1969) have reported the successful field testing of $\mathrm{Mg}$ bullets $(86 \% \mathrm{Mg}, \mathrm{I} 2 \%$ aluminium, $2 \% \mathrm{Cu}$ weighted with iron shot and releasing a total of about $0.5 \mathrm{~g}$ $\mathrm{Mg} / \mathrm{d}$ over a $20-\mathrm{d}$ period) to control hypomagnesaemic tetany in suckled calves. This would seem to be a useful method where suckled calves receive no creep feed. Table $\mathrm{I}$ indicates that both $\mathrm{Ca}$ and $\mathrm{Mg}$ (but not $\mathrm{P}$ ) supplementation will normally be required in creep feed for suckled calves.

Hill ewes and growing lambs. Table 2 details the minimum $\mathrm{Ca}, \mathrm{P}$ and $\mathrm{Mg}$ requirements (Agricultural Research Council, 1965) for a $40 \mathrm{~kg}$ hill ewe in mid and late pregnancy and during lactation with a single lamb. These intakes have been converted to the minimum dietary concentrations (\% dry matter) required calculated from typical dry matter-intakes given by Eadie ( 1967$)$. The mineral requirements are those for a single $15 \mathrm{~kg}$ lamb growing at $200 \mathrm{~g} / \mathrm{d}$ assuming that the ewe has a daily milk yield of I.51 (Agricultural Research Council, 1965). An additional herbage dry-matter intake of $0.25 \mathrm{~kg} / \mathrm{d}$ has been assumed. Benzie, Boyne, Dalgarno, Duckworth, Hill \& Walker $(1955,1956,1959,1960)$ have shown that ewes may draw on substantial amounts of skeletal material when given inadequate intakes of $\mathrm{Ca}$ or $\mathrm{P}$ during pregnancy and lactation and that these can be rapidly restored on an improved diet following weaning of their lambs. Table 2 indicates that the dietary $\mathrm{Ca}$ and $\mathrm{P}$ requirements of ewes are such that few hill herbages could meet the full $\mathrm{Ca}$ and $\mathrm{P}$ requirements of the ewe, especially during lactation on traditional hill pastures. The $\mathrm{Mg}$ requirement of the ewe during pregnancy is quite low but the $2 \cdot \mathrm{I} \mathrm{Mg} / \mathrm{d}$ required in lactation implies a concentration of $0.13-0.16 \% \mathrm{Mg}$ in the herbage dry matter. Davey ( 1968 ) has indicated that clinical hypomagnesaemic tetany was apparently only observed in lowland ewes grazing pasture with less than $0.07 \% \mathrm{Mg}$. Presumably many hill pastures may have $\mathrm{Mg}$ concentrations as low as this, but of equal importance will be the limitation in dry-matter intake alleviated only by the lower milk yield of the hill ewe. Older ewes, ewes with twins and the movement of ewes to alternate grazing shortly after lambing have been associated with the precipitation of hypomagnesaemic tetany (e.g. Hemingway \& Ritchie, I $9_{63}$ ). Table 2 suggests that the $P$ requirement of young lambs growing under the stated conditions are fully met by the milk supply but that there is an apparently substantial deficit between the Ca provided by the milk and the requirement. To a lesser extent there is an inadequate $\mathrm{Mg}$ intake. With the reduction in milk supply and an increase in herbage intake as the lamb gets older, a low $\mathrm{P}$ intake for the growing lamb would be more likely than an inadequate $\mathrm{Ca}$ supply. 
Table 2. Calcium, phosphorus and magnesium concentrations necessary in the drymatter (DM) intake of hill ewes and lambs to meet the minimum recommended (Agricultural Research Council, 1965) dietary intakes

\begin{tabular}{|c|c|c|c|}
\hline \multicolumn{4}{|l|}{$40 \mathrm{~kg}$ hill ewe-recommended intakes $(\mathrm{g} / \mathrm{d})$ : } \\
\hline $\begin{array}{l}\text { Mid pregnancy } \\
\text { Late pregnancy }\end{array}$ & $\begin{array}{l}3 \cdot 8 \\
6 \cdot 1\end{array}$ & $\begin{array}{l}3 \cdot 0 \\
4 \cdot 1\end{array}$ & $\begin{array}{l}0.48 \\
0.68\end{array}$ \\
\hline Lactation & II 0 & $7 \cdot 4$ & $2 \cdot 10$ \\
\hline \multicolumn{4}{|l|}{$40 \mathrm{~kg}$ hill ewe-dietary concentration required (\%): } \\
\hline $\begin{array}{l}\text { Mid pregnancy (900 g DM)* } \\
\text { Late pregnancy (I } 500 \mathrm{~g} \mathrm{DM}) * \\
\text { Lactation, some dead herbage (1350 g DM)* } \\
\text { Lactation with improved herbage (1 } 700 \mathrm{~g} \mathrm{DM})^{*}\end{array}$ & $\begin{array}{l}0.42 \\
0.41 \\
0.81 \\
0.65\end{array}$ & $\begin{array}{l}0.33 \\
0.27 \\
0.55 \\
0.44\end{array}$ & $\begin{array}{l}0.05 \\
0.05 \\
0.16 \\
0.13\end{array}$ \\
\hline \multicolumn{4}{|l|}{ I5 $\mathrm{kg}$ single lamb requirements: } \\
\hline $\begin{array}{l}\text { Growth at } 200 \mathrm{~g} / \mathrm{d}(\mathrm{g} / \mathrm{d}) \\
\text { Supplied in } 1.5 \mathrm{lmilk}(\mathrm{g} / \mathrm{d}) \\
\text { Dietary concentration at } 0.25 \mathrm{~kg} \text { DM ** d }(\%)\end{array}$ & $\begin{array}{l}3 \cdot 9 \\
2 \cdot 8 \\
4 \cdot 4\end{array}$ & $\begin{array}{l}1 \cdot 9 \\
2 \cdot 2 \\
\text { nil }\end{array}$ & $\begin{array}{l}0.40 \\
0.27 \\
0.52\end{array}$ \\
\hline
\end{tabular}

Marston (1934) concluded that young sheep grazing on P-deficient areas exhibited signs of protein shortage before any symptoms of aphosphorosis were observed and that the general condition of such animals had little in common with that of animals which were deficient only in respect of P. Young, growing sheep may be affected with a variety of osteodystrophic conditions. Nisbet, Butler, Bannatyne \& Robertson (1962) associated double scaup or cappi in sheep aged $5^{-12}$ months with aphosphorosis which was complicated by other dietary causes as the condition was seen to disappear following pasture improvement. Cresswell (1958) had earlier indicated that neither minerals nor vitamins reduced the incident of cappi and thought it possible that deficiencies of energy or protein were important in the aetiology. Nisbet, Butler, Smith, Robertson \& Bannatyne (I966) reported that rickets involving stiffness and lameness (but not dental abnormality) in 6-r2-month-old sheep resulted from inadequacy of $\mathrm{P}$ rather than $\mathrm{Ca}$ and that severity of the condition was increased where there was adequate pasture allowing fuller and more proper general growth.

The clinical condition of open mouth or dental mal-occlusion in to-month-old Blackface sheep together with a generalized osteoporosis has been ascribed to an inadequate $\mathrm{P}$ and vitamin $\mathrm{D}$ intake by Nisbet, Butler, Robertson \& Bannatyne (r 968 ). McRoberts, Hill \& Dalgarno ( $1965 a, b$, ) have also confirmed that inadequate dietary $\mathrm{P}$ is generally more serious than a shortage of $\mathrm{Ca}$ in a variety of dental and skeletal problems in young sheep. A severe osteoporosis in lactating ewes leading to a stiff and stilted gait (croiteach or cruban) has been described by Nisbet, Butler, Robertson \& Bannatyne (1970). They concluded that it was analagous to bog lame or cropac in lactating cattle in Ireland (O'Moore, 1950) and that both resulted from aphosphorosis.

Future developments in grazing management of hill pastures which lead to 
improved growth rates of lambs should be accompanied by measures which increase the $\mathrm{P}$ concentration of the herbage to more acceptable levels.

\section{Copper}

Swayback in ewes. The findings of early British workers (e.g. Shearer, Innes 8 McDougall, I940; Innes \& Shearer, 1940; Shearer \& McDougall, 1944) that swayback occurred in lambs where the concentrations of $\mathrm{Cu}$ in the herbage and in the blood and liver of ewes and their lambs were apparently much higher than under those conditions where an undoubted, simple $\mathrm{Cu}$ deficiency existed in Australia led to much initial confusion concerning the nature of the condition. Barlow, Purves, Butler \& MacIntyre (1960a,b), however, showed that the apparently high $\mathrm{Cu}$ concentrations previously described were partly attributable to soil contamination of herbage, inaccurate methods of analysis and unsuitable sampling dates. Comparisons between the two groups of workers are given in Table 3 . Current analyses obtained from recent outbreaks of swayback would seem to confirm the results of Barlow et al. $(1960 a, b)$. In further contrast to the findings of earlier workers, Butler \& Barlow (1963) and Hemingway, MacPherson \& Ritchie (1970) also found that ewe blood $\mathrm{Cu}$ concentrations fell markedly during pregnancy and rose after parturition. Allcroft, Clegg \& Uvarov (1959) considered that the reduction may be due to the restriction in the total amount of herbage for consumption during pregnancy and an improvement of intake after lambing. MacPherson \& Hemingway (I968) found this to be the situation with non-pregnant sheep maintained on restricted herbage during winter, followed by an improvement associated with spring growth.

Table 3. Concentrations of copper $(p p m)$ in herbage, ewe blood and lamb liver associated with swayback as determined by two groups of investigators

\begin{tabular}{|c|c|c|c|}
\hline & & $A *$ & $\mathrm{~B}^{* *}$ \\
\hline Herbage dry matter & $\begin{array}{c}\text { Mean } \\
\text { Range } \\
\% \text { below } 5.0\end{array}$ & $\begin{array}{c}14 \cdot 8 \\
4 \cdot 4-22 \cdot 2 \\
?\end{array}$ & $\begin{array}{c}5 \cdot 8 \\
I \cdot 8-25 \cdot 5 \\
62\end{array}$ \\
\hline Ewe blood & $\begin{array}{c}\text { Mean } \\
\text { Range } \\
\% \text { below } 0.30\end{array}$ & $\begin{array}{c}0.64 \\
0.30-x \cdot 10 \\
0\end{array}$ & $\begin{array}{c}0.13 \\
0.05-0.4 I \\
94\end{array}$ \\
\hline Lamb liver dry matter & $\begin{array}{c}\text { Mean } \\
\text { Range } \\
\% \text { below 8.0 }\end{array}$ & $\begin{array}{c}12 \cdot 0 \\
4 \cdot 0-18 \cdot 0 \\
14\end{array}$ & $\begin{array}{c}5.6 \\
I \cdot 0-12 \cdot 0 \\
9 I\end{array}$ \\
\hline
\end{tabular}

There is much practical field experience which suggests that pasture improvement, and particularly liming, leads to an increase in the incidence of swayback, for example Dunlop \& Wells (1938) and Barlow et al. (1960a, b) considered that an abundance of herbage during a mild winter was conducive to swayback. In part, this may be due to a more restricted use of supplementary feeds which would normally contain more $\mathrm{Cu}$ than herbage. Nevertheless, cases of swayback have been observed even 
where ewes at grass have received concentrates containing $18 \mathrm{ppm} \mathrm{Cu}$ in amounts increasing to I $\mathrm{kg} / \mathrm{d}$ during the weeks before lambing.

The increasing use of urea would tend to reduce the amount of $\mathrm{Cu}$ present in ewe nuts.

Direct experimental evidence relating the use of lime to the incidence of swayback is not available. Several workers (e.g. Reith \& Mitchell (r964) and MacPherson \& Hemingway ( 1968 ) were not able to show any consistent depressive effect on the $\mathrm{Cu}$ concentration in herbage resulting from the use of lime. MacPherson \& Hemingway ( 1968 ) did however show that the concentration of $\mathrm{Cu}$ in the blood of non-pregnant sheep maintained over a period of I year were consistently reduced by grazing on limed herbage but that the seasonal fall from late autumn (c. I.0 ppm) throughout the winter on restricted herbage to late April (c. $0.5 \mathrm{ppm})$ and the sudden rise in early May (c. I.० ppm) associated with early spring growth was much more important. Sheep grazing the limed area had a mean concentration of $19.3 \mathrm{ppm} \mathrm{Cu}$ in the liver compared with $63^{\cdot 1} \mathrm{ppm}$ where lime had not been applied.

Injection of suitable $\mathrm{Cu}$-containing compounds supplying about $40-50 \mathrm{mg} \mathrm{Cu}$ (e.g. copper methionate, copper glycine, copper calcium EDTA) in mid pregnancy have been shown to be effective in both preventing swayback and increasing the concentrations of $\mathrm{Cu}$ in the ewe blood and in the blood and liver of lambs born to treated ewes (Hemingway et al. 1970; Allcroft \& Uvarov, 1959). Copper sulphate (about $3 \mathrm{~g}$ given in two doses in the second half of pregnancy) is also effective (and much cheaper) in preventing swayback, for example Barlow et al. (1960b) reported that the incidence of swayback in one trial was reduced from $23 \%$ to $3 \%$. However, copper sulphate produces much smaller increases in the $\mathrm{Cu}$ concentration of the lamb liver than does the use of injectable $\mathrm{Cu}$ compounds (Hemingway et al. 1970).

Hill cows and suckled calves. Copper deficiency in suckled calves appears to be widespread and is not necessarily confined to those areas or farms where swayback in lambs is encountered. The minimum recommended concentration of $\mathrm{Cu}$ in the diet of cattle is ro ppm (Agricultural Research Council, r965) compared with 5 ppm for sheep. Undoubtedly, many hill pastures in winter contain less than to ppm $\mathrm{Cu}$ and Hemingway et al. (1968) have found that $9 \mathrm{I} \%$ of hays and $62 \%$ of silages grown in Scotland contain less than ro ppm $\mathrm{Cu}$. A low $\mathrm{Cu}$ intake by the hill cow presumably contributes to the poor $\mathrm{Cu}$ status of the calf at birth. A good case exists for the use of $\mathrm{Cu}$ supplemented foods and appropriate $\mathrm{Cu}$ injections where the need is shown to exist.

Many calves exhibiting distressing signs of $\mathrm{Cu}$ deficiency (severe scour, dirty and staring coats, general unthriftiness) respond remarkably rapidly, i.e. within a few days to supplementary oral $\mathrm{Cu}$ ( $\mathrm{I} \mathrm{g} \mathrm{CuSO}_{4} \cdot 5 \mathrm{H}_{2} \mathrm{O}$ ) and show a continued improvement in vigour and condition. 


\section{REFERENCES}

Agricultural Research Council. ( 1965 ). The Nutrient Requirements of Farm Livestock No.2. London: H.M. Stationery Office.

Allcroft, R. (1960). British Veterinary Association Conjerence on Hypomagnesaemia p. 102. London.

Allcroft, R., Clegg, F. ${ }^{\text {G. }}$ \& Uvarov, O. (1959). Vet. Rec. 7r, 884 .

Allcroft, R. \& Uyarov, O. (1959). Vet. Rec. 7x, 797.

Barlow, R. M., Purves, D., Butler, E. J. \& MacIntyre, I. J. (r g6oa). F. comp. Path. 70, 396.

Barlow, R. M., Purves, D., Butler, E. J. \& MacIntyre, I. J. (1960b). F. comp. Path. 70, 411.

Benzie, D., Boyne, A. W., Dalgarno, A. C., Duckworth, J., Hill, R. \& Walker, D. M. (1955). J. agric. Sci., Camb. 46, 425.

Benzic, D., Boyne, A. W., Dalgarno, A. C., Duckworth, J., Hill, R. \& Walker, D. M. (1956). f. agric. Sci. Camb. 48, r75.

Benzie, D., Boyne, A. W., Dalgarno, A. C., Duckworth, J., Hill, R. \& Walker, D. M. (1959). Y. agric. Sci., Camb. 52, I.

Benzie, D., Boyne, A. W., Dalgarno, A. C., Duckworth, J., Hill, R. \& Walker, D. M. (I960) J. agric. Sci., Camb. 54, 202.

Butler, E. J. \& Barlow, R. M. (1963). \%. comp. Path. 73, 107.

Calder, A. B. \& Voss, R. C. (1957). Consultative Committee for Development of Spectrographic Work. Bull. no. I. Macaulay Institute for Soil Research, Aberdeen.

Cresswell, E. (1958). F. agric Sci., Camb. 50, in 5.

Cunningham, I. J. (1936a) N.Z. Il Sci. Technol 18, 419.

Cunningham, I. J. (1936b). N.Z. Yl Sci. Technol. 18, 424 .

Davey, L. A. (1968). Vet. Rec. 82, I42.

Dunlop, G. \& Wells, H. E. (1938). Vet. Rec. 37, I175.

Eadie, J. (1967). Rep. Hill Fmg Res. Org. No. 4, p. 38.

Hemingway, R. G., MacPherson, A., Duthie, A. K. \& Brown, N. A. (Ig68). f. agric. Sci., Camb. 7I, 53.

Hemingway, R. G., MacPherson, A. \& Ritchie, N. S. (1970). In Trace Element Metabolism in Animals p. 264 [C. F. Mills, editor]. Edinburgh and London: E. \& S. Livingstone.

Hemingway, R. G. \& Ritchie, N. S. (1963). F. Sci. Fd Agric, x4, 162.

Hemingway, R. G. \& Ritchie, N. S. (1969). Vet. Rec. 83, 465.

Inglis, J. S. S., Weipers, M. \& Marr, A. (I954). Vet. Rec. 66, 353.

Innes, J. R. M. \& Shearer, G. D. (1940). F. comp. Path. 53, x.

Jones, D. I. H. (1970). Nature, Lond. 226, 772.

Kleiber, M., Goss, H. \& Guilbert, H. R. (1936). F. Nutr. 12, 12x.

Little, D. A. (1968), Proc. Aust. Soc. Anim. Prod. 7, 376.

MacPherson, A. \& Hemingway, R. G. (1968). F. Sci. Fd Agric, 19, 53.

McRoberts, M. R., Hill, R. \& Dalgarno, A. C. (1965a). F. agric. Sci., Camb. 65, 1.

McRoberts, M. R., Hill, R. \& Dalgarno, A. C. (1965b). F. agric. Sci., Camb. 65, ir.

Marston, H. R. (1934). Bull. Commonw. Scient. ind. Res, org. Aust. no. 85, p. 7.

Mitchell, R. L. (1954). F. Br. Grassld Soc. 9, 30r.

Nisbet, D. I., Butler, E. J., Bannatyne, C. C. \& Robertson, J. M. (1962). F. comp. Path. 72, 270.

Nisbet, D. I., Butler, E. J., Robertson, J. M. \& Bannatyne, C. C. (1968). F. comp. Path. 78, 73.

Nisbet, D. I., Butler, E. J., Robertson, J. M. \& Bannatyne, C. C. (1970). F. camp. Path. 80, 535.

Nisbet, D. I., Butler, E. J., Smith, B. S. W., Robertson, J. M. \& Bannatyne, C. C. (1966) F. comp. Path. 76,159 .

O'Moore, L. B. (1950). Ir. vet. F. 4, 198, 218.

Playne, M. J. (1969). Aust. F. exp. Agric. Anim. Husb. 9, 192.

Reith, J. W. S. \& Mitchell, R. L. (1964). Plant Analysis and Fertiliser Problems p. 241. East Lansing: American Society of Horticultural Science.

Shearer, G. D., Innes, J. R. M. \& McDougall, E. I. (1940). Br. vet. F. 96, 309.

Shearer, G. D. \& McDougall, E. I. (I944). F, agric. Sci., Camb. 34, 207

Smith, R. H. (1964). Int. Meet. Dis. Cattle, In Copenhagen. Nord. VetMed., r964, Suppl. no. 1, p. 143.

Thomas, B., Escritt, J. R. \& Trinder, N. (1945) Emp. F. exp. Agric. 13, 92.

'Thomas, B., Thompson, A., Oyenuga, V. A. \& Armstrong, R. H. (1952). Emp. F. exp. Agric. 20, 10.

Thomas, B. \& Trinder, N. (1947). Emp. F. exp. Agric. 15, 237.

Thompson, A. \& Raven, A. M. (I955). \%. Sci. Fd Agric. 6. 768 